\title{
ANALISIS KADAR RESIDU ANTIBIOTIK DALAM DAGING AYAM POTONG YANG BEREDAR DI KOTA MATARAM
}

\section{QUANTITATIVE ANALYSIS OF ANTIBIOTIC RESIDUE IN CHICKEN FROM MATARAM}

\author{
Sahri Yanti ${ }^{1}$, Surya Hadi $^{2}$, Lely Kurniawati ${ }^{2}$ \\ 1Program Studi Teknologi Hasil Pertanian Fakultas Teknologi Pertanian, UTS, NTB \\ ${ }^{2}$ Program Studi Kimia Fakultas Matematika dan Ilmu Pengetahuan Alam, Universitas Mataram, NTB. \\ sahri.farwana@gmail.com/sahriyanti@uts-sumbawa.ac.id
}

\begin{abstract}
ABSTRAK
Analisis kuantitatif residu antibiotik dalam daging ayam potong yang beredar di Kota Mataram telah dilakukan dari bulan September hingga Oktober 2011. Pengambilan sampel dilakukan secara acak di tiga lokasi Pasar, Supermarket HERO, KFC dan Kentuku. Analisis kimia yang dilakukan melibatkan proses ekstraksi, sentrifugasi dan pengukuran dengan HPLC. Pada proses ekstraksi, pelarut yang digunakan yaitu Mcilvaine EDTA yang mampu memisahkan antibiotik dalam daging. Analisis kualitatif dengan HPLC mengindikasikan keberadaan residu antibiotik Oksitetrasiklin dalam sampel daging ayam potong dari Kota Mataram. Kadar residu antibiotik Oksitetrasilin yang telah ditemukan lebih kecil dari batas maksimum 1 ppm yang ditetapkan FAO. Kadar residu antibiotik Oksitetrasiklin dalam sampel masing-masing lokasi yaitu Seganteng 0,353 ppm, Bertais 0,259 ppm, Sesela 0,190 ppm, Sweta 0,172 ppm, Hero 0,157 ppm, KFC 0,113 ppm dan Kentuku 0,092 ppm.
\end{abstract}

Kata kunci: Residu Antibiotik, Mcilvaine EDTA, Oksitetrasiklin, HPLC.

1.

\section{PENDAHULUAN}

Daging ayam potong bukanlah istilah yang asing dan populernya daging tersebut disebabkan oleh daya beli masyarakat yang rendah sehingga menjadikannya sebagai alternatif pengganti daging lainnya, seperti daging sapi dan daging kambing. Kebutuhan masyarakat terhadap daging ayam potong terlihat dari besarnya populasi ternak ayam potong di Kota Mataram (Dinas Peternakan NTB, 2011). Populasi ternak ayam yang tinggi perlu diwaspadai karena pemeliharaannya diiringi oleh penggunaan antibiotik yang intensif. Menurut Levy (1992), antibiotik ternak pedaging yaitu Tetrasiklin, Penicillin, Neomicin, Streptomicin dan derifat Sulfur, namun yang sering digunakan oleh industri peternakan ayam yakni yang memiliki spektrum luas, seperti Tetrasiklin (Lawrie, 1985).

Anief (1990) menyebutkan bahwa antibiotik merupakan obat yang mampu menghambat atau membunuh bakteri, namun antibakteri merupakan obat pembunuh bakteri. Toksisitas antibiotik bersifat selektif, artinya jika difungsikan untuk ayam, maka antibiotik tersebut aman bagi ayam, namun bersifat racun bagi mikroorganisme patogen dalam tubuh ayam (Komara, 2010). Antibiotik dapat menghambat sintesis materi yang penting dari sel bakteri dalam tubuh manusia (Anief, 1990). Selama absorbsi, distribusi dan ekskresi, antibiotik juga mengalami biotransfomasi. Murtidjo (2003) menyebutkan bahwa biotranformasi dapat merubah struktur kimia obat menjadi lebih mudah larut dalam air. Tempat terpenting biotransformasi adalah hati, namun terjadi juga di paru-paru, lambung, usus, kulit dan ginjal. Hati merupakan mesin metabolik dan dapat menginaktifkan obat yang melintasi saluran gastrointestinal menuju seluruh tubuh (Stringer, 2009).

Hasil penelitian pada tahun 1998 menemukan residu beberapa jenis antibiotik dalam daging ayam broiler di wilayah Kota Mataram (Sriasih, 1998). Menurut Levy (1992) pemakaian antibiotik dalam jumlah besar akan menimbulkan masalah bagi manusia diantaranya terjadi seleksi dari bakteri yang resisten terhadap antibiotik, akhirnya menyebabkan kerusakan pada jaringan tubuh. Salah satu dampak residu antibiotik adalah alergi terhadap daging ayam. Hal ini merupakan reaksi hipersensitivitas terhadap 
komponen yang tidak diketahui dalam tubuh pasien (Mansur, 2001).

Berdasarkan data kunjungan tim puskesmas di Kota Mataram tahun 2008, alergi menempati urutan ke-6 sebanyak 25.154 pasien (Depkes RI, 2008). Mursyidi (2004) menambahkan bahwa kompleksitas penyakit yang menyerang menuntut penggunaan antibiotik secara tepat. Pelarangan tersebut telah lama diterapkan di Eropa pada antibiotik untuk hewan ternak yang mengakibatkan resistensi kuman dalam tubuh manusia (Yamin, 2008). Mengingat bahaya residu antibiotik dalam daging ayam potong yang dikonsumsi oleh masyarakat, maka telah dilakukan analisis kadar residu antibiotik dalam daging ayam potong yang beredar di Kota Mataram.

Adapun rumusan masalah yang telah dikaji yakni: (a) jenis antibiotik apa saja yang umum digunakan oleh peternak ayam potong di Kota Mataram? (b) berapa kadar residu antibiotik yang terdapat dalam daging ayam potong yang beredar di Kota Mataram berdasarkan hasil analisa HPLC? (c) bagaimanakah perbandingan batas mak-simum penggunaan antibiotik dengan kadar residu antibiotik dalam sampel daging ayam potong dari Kota Mataram?.

Penelitian diharapkan dapat mengetahui jenis antibiotik yang umum digunakan dan kadar residunya dalam sampel daging ayam potong yang beredar di Kota Mataram. Hal tersebut merupakan upaya pengendalian dampak negatif residu antibiotik terhadap kesehatan masyarakat di Kota Mataram. Manfaat lainnya yaitu sebagai informasi bagi pemerintah Kota Mataram terhadap ancaman kesehatan masyarakat dan diharapkan adanya penyuluhan kepada para peternak ayam potong mengenai cara pemberian antibiotik yang benar, serta memberi pengawasan yang ketat terhadap penggunaan antibiotik hewan.

\section{METODE PENELITIAN}

\subsection{Alat}

Adapun alat - alat yang digunakan yaitu: Kolom $\mathrm{C}_{18}$ RSIL, HPLC, Detektor UV, Reader Shimadzu, timbangan analitik, $\mathrm{pH}$ meter, blender, penggojok, sentrifugasi, kertas saring $0,4 \mu \mathrm{m}$ (wilex), kertas saring membran $0,2 \mu \mathrm{m}$, tabung reaksi, gelas kimia $1000 \mathrm{~mL}$, labu takar $25 \mathrm{~mL}$, gelas ukur $25 \mathrm{~mL}$, pengaduk, pipet mikro $1000 \mu \mathrm{L}$, pipet tetes, aluminium foil, pisau, talenan dan baskom kecil.

\subsection{Bahan}

Bahan yang dibutuhkan yakni: daging ayam potong segar, es batu, metanol $\left(\mathrm{CH}_{3} \mathrm{OH}\right)$, aquades, $\mathrm{Na}_{2}$-EDTA, sodium posfat $\left(\mathrm{Na}_{2} \mathrm{HPO}_{4} .2 \mathrm{H}_{2} \mathrm{O}\right)$, asam sitrat $\left(\mathrm{C}_{6} \mathrm{H}_{8} \mathrm{O}_{7}\right)$, Coryvit, Corydon dan amonium sulfat $\left(\mathrm{NH}_{4}\right)_{2} \mathrm{SO}_{4}$.

\subsection{Pembuatan Reagen}

a Pembuatan pelarut $\mathrm{Na}_{2}$ EDTA (buffer posfat pH 4) $0,1 \mathrm{M}$

Tambahkan 30,245 gr Na- EDTA kemudian larutkan dalam 812,5 mL buffer posfat.

b Pelarut elusi (20\% aquades dan $80 \%$ metanol)

Eluen A: Sediakan metanol sebanyak 200 $\mathrm{mL}$. Eluen B: Saring aquades sebanyak $250 \mathrm{~mL}$ dengan kertas saring $0,2 \mu \mathrm{m}$.

\subsection{Larutan Standar Antibiotik}

Timbang masing - masing 1 gr Coryvit dan 2 gr Corydon, kemudian larutkan dengan metanol dan ditepatkan $25 \mathrm{~mL}$. Konsentrasi awal masing - masing larutan standar yaitu 4000 ppm. Pengenceran selanjutnya dilakukan hingga konsentrasi mencapai 3000 ppm, 2000 ppm, 1000 ppm.

\subsection{Preparasi sampel}

Bagian lemak sampel dipisahkan dan diblender dengan kecepatan tinggi selama 15 - 30 detik. Sebanyak 5 gr simplisia ditambahkan dengan $2 \mathrm{~mL}$ amonium sulfat jenuh dan $18 \mathrm{~mL}$ larutan Mcilvaine EDTA. Simplisia digojok dengan sheker $155 \mathrm{rpm}$ selama 30 menit dan diputar $3000 \mathrm{rpm}$ selama 10 menit. Supernatan dipisahkan dari residunya, dan diekstraksi kembali dengan menambahkan $10 \mathrm{~mL}$ Mcilvaine EDTA, selanjutnya diputar dengan kecepatan 3000 rpm selama 10 menit kemudian disaring dengan wilex.

\subsection{Injeksi Sampel}

Kolom HPLC diaktifkan dengan metanol dan air pada suhu kamar. Dimasukkan $10 \mathrm{~mL}$ standar ke dalam kolom yang telah diaktifkan. Didiamkan selama 5 menit, kemudian dielusi dengan fase gerak metanol dan air dengan perbandingan $1: 1$, dan laju alir diatur 0,6 
$\mathrm{mL} /$ detik. Fase diam pada HPLC yaitu silika C18 Bondapak, sedangkan reader yang digunakan yaitu Simatzu. Sampel dan larutan standar diinjeksikan dengan syiring berskala $100 \mu \mathrm{L}$, dan sebanyak $10 \mu \mathrm{L}$ standar dan supernatan diinjeksikan dalam HPLC.

\section{HASIL DAN PEMBAHASAN}

Larutan standar dibuat dengan mengencerkan antibiotik Oksitetrasiklin dan Ampicillin yang masing - masing bermerek
"CORYDON" dan "CORYVIT". Keduanya merupakan antibiotik yang dijual secara bebas di Kota Mataram. Masing - masing antibiotik diencerkan dengan metanol. Metanol dapat melarutkan berbagai senyawa organik yang sukar larut dalam air (Rivai, 2006). Semakin kecil konsentrasi antibiotik dalam metanol, semakin pudar. Konsentrasi awal larutan standar yaitu $4000 \mathrm{ppm}$. Berikut variasi warna antibiotik :
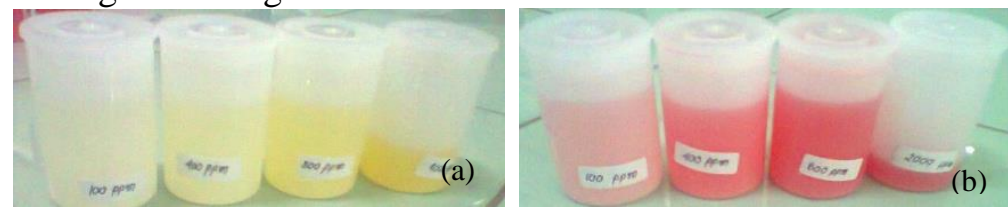

Gambar 1. Coryvit (a) Corydon (b)

\subsection{Pengenceran Coryvit dengan Metanol}

Coryvit mengandung Oksitetrasiklin

$\mathrm{HCl} 100 \mathrm{mg} / \mathrm{gr}$ dan Neomycin sulfat 110 $\mathrm{mg} / \mathrm{gr}$. Sebelum diencerkan, produk Coryvit merupakan serbuk halus berwarna kuning muda. Auterhoff dan Kovar (2002) juga menyebutkan hal yang sama, yakni golongan Tetrasiklin merupakan antibiotik yang berwujud serbuk kuning dan tidak berbau, sedangkan Neomycin berwarna putih, tidak berbau, pahit, tahan terhadap cahaya dan udara.

Pengenceran Coryvit dengan metanol me-nyebabkan perubahan warna kuning menjadi merah serta muncul endapan putih. Terbentuknya endapan dikarenakan tidak semua antibiotik dalam Coryvit mudah larut dengan metanol. Antibiotik yang mudah larut dalam metanol yaitu Oksitetrasiklin, sedangkan Neomycin bersifat sebaliknya. Endapan Neomycin yang terbentuk akan menghilang jika Coryvit dilarutkan kembali dengan dalam aquades. Schunack et all (1990) menyebutkan $20 \mathrm{mg} / \mathrm{mL}$ Oksitetrasiklin larut dalam pelarut metanol dan $1,7 \mathrm{mg} / \mathrm{mL}$ larut dalam air. Rendahnya kelarutan Oksitetrasiklin dalam air disebabkan oleh sifat gugus benzena yang sukar larut dalam air.

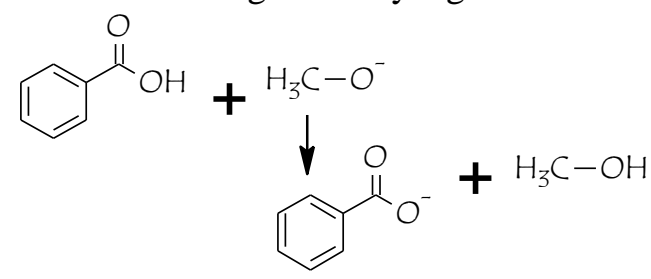

Gambar 2.

Reaksi Benzena dengan Metanol dalam Suasana Asam (Rivai, 2006):

Menurut Svehla (1985) dan Tjahajati (2008), Neomycin sulfat terdiri dari anion sulfat yang bersifat higroskopik dan rantai amina yang terhubung dengan senyawa glikosidik. Amina larut dalam air karena dapat membentuk ikatan hidrogen dengan molekul air.

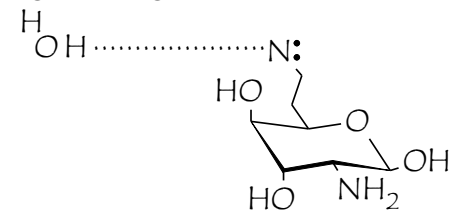

Gambar 3. Ikatan Hidrogen (Fessenden, 1982).

\subsection{Pengenceran Corydon dengan Metanol}

Corydon terbuat dari antibiotik Ampicillin trihidrat $50 \mathrm{mg} / \mathrm{gr}$ dan Colistin sulfat 12,195 mg/gr. Pengenceran dengan metanol menghasilkan larutan kuning. Menurut Svehla (1985), Departemen Kesehatan RI (1995) dan Fessenden (1982) Colistin sulfat memiliki anion sulfat bersifat higroskopik, sukar larut dalam metanol, berbentuk serbuk putih kekuningan, tersusun dari polipeptida sederhana 
dengan BM kurang dari $1000 \mathrm{gr} / \mathrm{mol}$ dan dihubungkan oleh ikatan hidrogen yang mudah dirusak oleh alkohol.

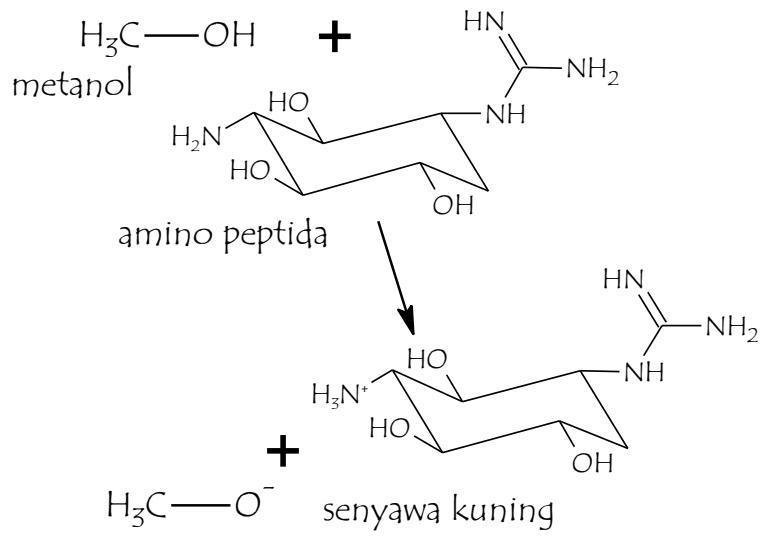

\section{Gambar 4. Reaksi Alkohol dengan Amino Peptida}

Pengenceran Corydon menghasilkan endapan yang berasal dari sisa antibiotik Colistin dan Ampicillin. Ampicillin berwujud bubuk halus, putih, higroskopik dan sukar larut dalam metanol. Kelarutannya dalam air memiliki perbandingan 1:150 (Auterhoff dan Kovar, 2002).

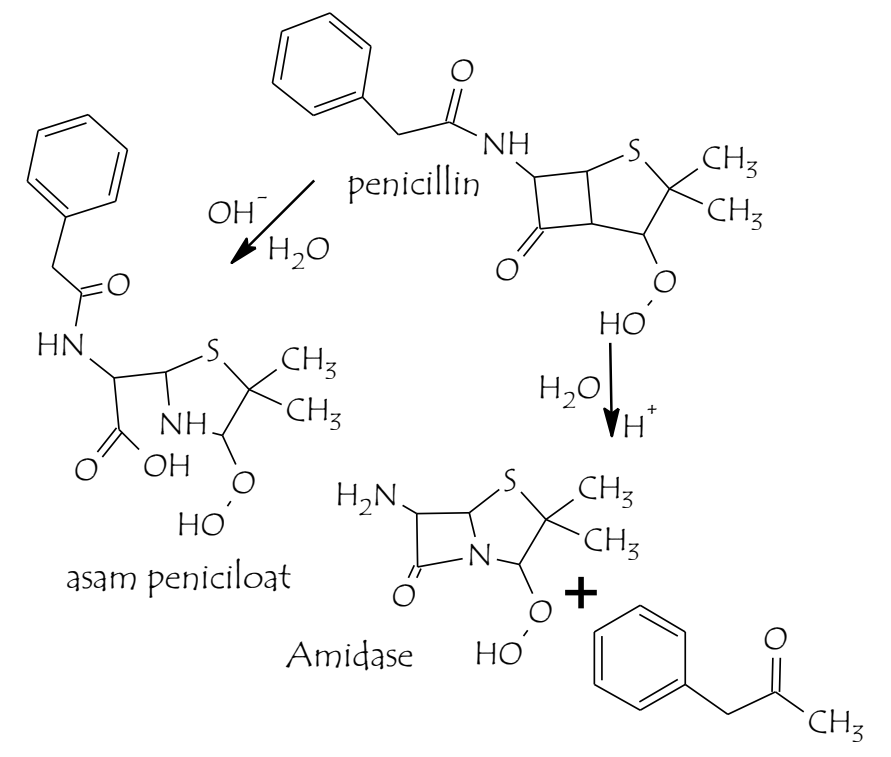

Gambar 5. Reaksi Ampicillin dengan Air (Sudjadi, 2007)

\subsection{Ekstraksi Daging Ayam Potong}

Ekstraksi dilakukan dengan Mcilvaine EDTA pH 4. Sebelum diekstraksi, daging terlihat berwarna merah menunjukkan mioglobin, yaitu protein pigmen yang mirip dengan hemoglobin darah. Mioglobin banyak terdapat pada bagian tubuh yang aktif bergerak, seperti paha (Murtidjo, 2003). Jika bereaksi dengan oksigen, mioglobin akan berwarna merah cerah, namun jika tidak bereaksi dengan oksigen akan cenderung berwarna ungu. Selain protein, daging ayam juga mengandung lemak dan air sekitar 75\% - 80\%.

Ekstrak yang dihasilkan berwarna putih pucat dan membentuk gumpalan akibat perubahan struktur serta komposisi protein (denaturasi) dalam daging ayam. Denaturasi dapat dipicu oleh penggunaan buffer $\mathrm{pH} 4$ (asam), panas dan alkohol. Hal tersebut juga ditegaskan oleh Winarno (2004) yakni bila susunan rantai polipeptida suatu molekul protein berubah dapat dikatakan bahwa protein tersebut terdenaturasi. Faktor yang mengakibatkan denaturasi protein antara lain faktor kimia dan fisika. Menurut Panil (2007), faktor kimia yang dimaksud berupa penambahan larutan asam, basa, garam dan logam berat. Sedangkan salah satu faktor fisika yaitu penggojokan

Protein dapat menghambat aliran sampel dalam kolom, sebab dapat bereaksi dengan metanol (eluen). Oleh karena itu, 
sampel harus terbebas dari protein. Penghilangannya dilakukan dengan cara penambahan garam ammonium sulfat jenuh kemudian disentrifugasi. Protein dengan berat molekul yang besar akan mengendap dengan cepat.

\subsection{Analisis Kuantitatif dengan HPLC - Detektor UV}

Uji linearitas dilakukan dengan membuat kurva kalibrasi dari konsentrasi larutan standar dan luas puncak. Persamaan regresi yang diperoleh untuk antibiotik Oksitetrasiklin yaitu $\mathrm{y}=7,898 \mathrm{x}$, dan antibiotik Ampicillin yaitu $\mathrm{y}=8,992 \mathrm{x}$. Masing - masing antibiotik memiliki nilai koefisien korelasi sebesar 0,959 dan 0,929 . Oksitetrasiklin

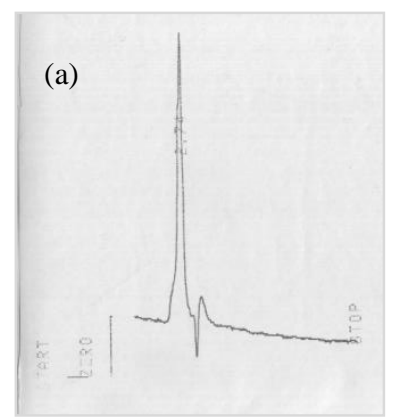

Gambar 6. Kromatogram HPLC Oksitetrasiklin (a) Ampicillin (b)

Analisis sampel menggunakan HPLC menghasilkan kromatogram dengan luas area yang berbeda - beda. Sem akin besar luas area, semakin besar pula konsentrasi antibiotik. Konsentrasi masing - masing antibiotik dihitung berdasarkan rumus berikut:

$$
C_{s}=\frac{\frac{A_{s}}{A_{s t d}} \times C_{s t d} \times V_{t}}{m_{g}}
$$

$\mathrm{C}_{\mathrm{s}}$ adalah konsentrasi sampel, $\mathrm{C}_{\mathrm{std}}$ adalah konsentrasi standar, $\mathrm{A}_{\mathrm{s}}$ adalah luas puncak sampel, $\mathrm{A}_{\text {std }}$ adalah puncak standar, $\mathrm{V}_{\mathrm{t}}$ adalah Volume akhir sampel $(\mathrm{L})$, dan $\mathrm{m}_{\mathrm{g}}$ adalah berat sampel.(mg). Konsentrasi standar $\left(\mathrm{C}_{\text {std }}\right)$ yang digunakan yaitu $2000 \mathrm{ppm}$, luas puncak standar $\left(\mathrm{A}_{\text {std }}\right)$ yaitu 15796 dan volume total $\left(V_{t}\right)$ sebanyak $0,03 \mathrm{~L}$. Nilai $V_{t}, C_{\text {std }}$, dan $A_{\text {std }}$ adalah sama, variabel yang berubah yaitu $A_{s}$ dan $m_{g}$.

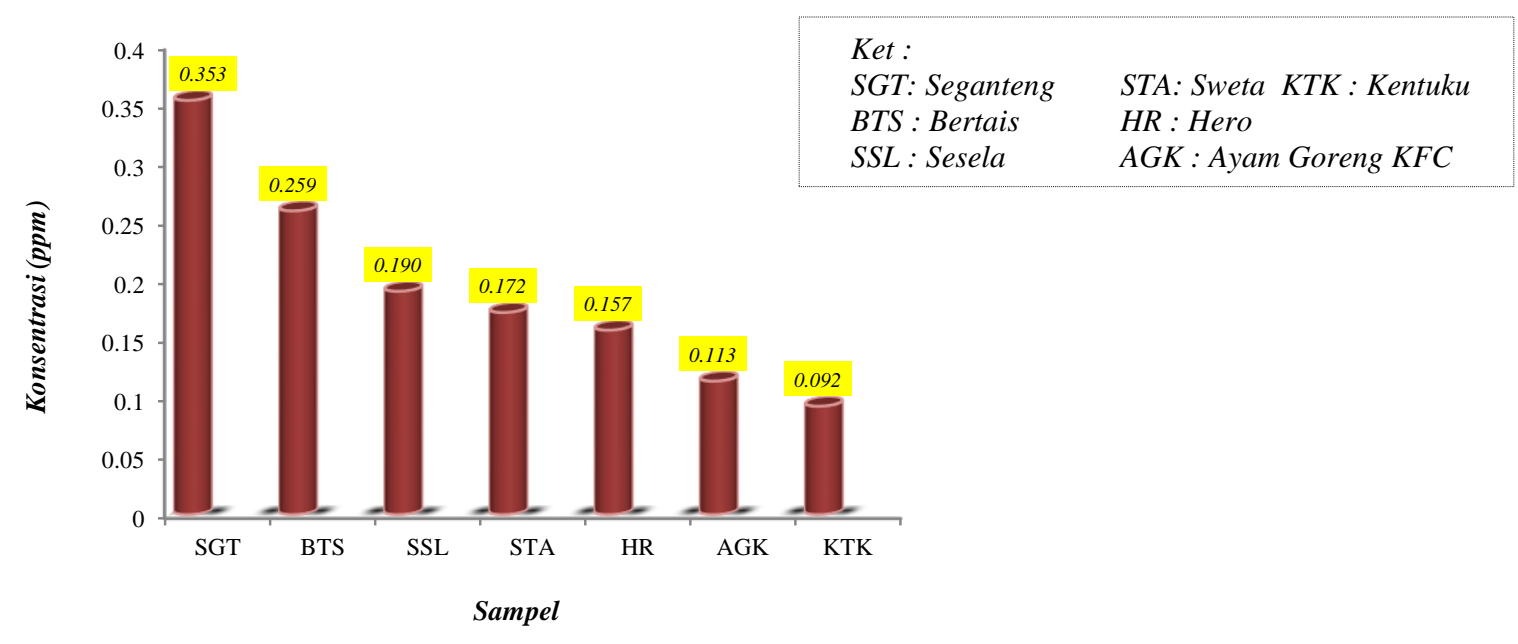




\section{Gambar 7. Diagram Residu Oksitetrasiklin Dalam Sampel Kota Mataram}

Berdasarkan diagram di atas, rerata residu Oksitetrasiklin yang terdapat dalam daging ayam potong yakni 0,191 ppm dan Ampicillin tidak terdeteksi. Batas maksimum yang ditetapkan FAO untuk Oksitetrasiklin adalah 1 ppm dan jika dibandingkan dengan rerata tersebut, maka semua sampel daging ayam potong dari Kota Mataram memiliki kadar residu di bawah batas maksimum. Rendahnya angka rerata kadar residu antibiotik Oksitetrasiklin dalam sampel daging ayam potong dari kota Mataram, menginformasikan bahwa secara umum daging ayam potong yang beredar di Kota Mataram cukup aman dari antibiotik Oksitetrasiklin.

\section{KESIMPULAN}

Antibiotik yang umum digunakan oleh peternak ayam potong di Kota Mataram yaitu antibiotik dari golongan Tetrasiklin berjenis Oksitetrasiklin dan golongan Penicillin berjenis Ampicillin. Kadar residu Oksitetrasiklin dalam masing - masing sampel yaitu Seganteng, Bertais, Sesela, Sweta, Hero, KFC dan Kentuku dengan kadar berturut turut yakni: $0,353 \mathrm{ppm}, 0,259 \mathrm{ppm}, 0,190$ ppm, 0,172 ppm, 0,157 ppm, 0,113 ppm dan 0,092 ppm. Jumlah rerata residu Oksitetrasiklin yang ditemukan dalam daging ayam potong dari Kota Mataram yaitu 0,191 ppm, sedangkan residu Ampicillin tidak terdeteksi. Semua sampel memiliki kadar residu antibiotik Oksitetrasiklin di bawah batas maksimum penggunaan antibiotik Oksitetrasiklin yakni $1 \mathrm{ppm}$ yang ditetapkan FAO.

\section{DAFTAR PUSTAKA}

Anief, Moh. 1990. Penggolongan Obat Berdasarkan Khasiat dan Penggunaan. Yogyakarta. Gadjah Mada University Press.

Auterhoff dan Kovar, 2002. Identifikasi Obat. Bandung: ITB

Departemen Kesehatan RI. 1995. Farmakope Indonesia Edisi IV. Jakarta: Direktorat Jendral Pengawasan Obat dan Makanan.

Departemen Kesehatan RI. 2008. "Profil Kesehatan Kota Mataram 2008". http://www.depkes .go.id. Diakses pada hari Jumat, 3/2012.

Dinas Peternakan Provinsi NTB. 2011. "Grafik Populasi ternak Provinsi NTB
(2008-2010)".

http://www.disnakkeswanntb@yahoo .co.id. Diakses pada hari Senin, 11/04/2011.

Erlan. 2009. Makalah Kimia Antibiotik Dalam Ternak. Garut: Universitas Garut Press.

Fessenden dan Fessenden. 1982. Kimia Organik. Jakarta: Erlangga.

Komara, Toni. 2010."Review Antibiotik Untuk Ayam". http://masenchipz.com. Diakses pada hari Kamis, 31/03/2011.

Lawrie, R.A. 1985. Ilmu Daging Edisi ke 5. Diterjemahkan Oleh Parakkasi. A. Jakarta: Universitas Indonesia Press.

Levy, Stuart B.,M.D., 1992. The Antibiotik Paradox. Plenum Press, Newyork and Lodon.

Mansur. 2008. "Toksikologi dan Distribusi Agen Toksik". http://library.usu.ac.id. Diakses pada hari Minggu, 17/4/2011.

Mursyidi, Achmad. 2004. Peran Analisis kimia Bagi Kehidupan manusia. Surakarta: Muhammadiyah University Press.

Murtidjo, Bambang Agus. 2003. Pemotongan dan Penanganan Daging Ayam. Yogyakarta: Kanisius.

Panil, Zulbadar. 2007. Memahami Teori dan Praktek Biokimia Dasar Medis. Jakarta : EGC.

Rivai, Harizul. 1995. Asas Pemeriksaan Kimia. Jakarta: UI Press.

Schunack W, Mayer K, Haake M. 1990. Senyawa Obat, Buku Pelajaran Kimia Farmasi. Penerjemah; Padmawinata, Yogyakarta: UGM Press.

Sriasih, Made., Maskur., Hasil Tamzil. 1998. Laporan Penelitian Analisis Residu Beberapa Jenis Antibiotika Pada Daging Ayam Broiler. Dibiayai Dana SPP/DPP Universitas Mataram Tahun 1997/1998, Surat Kontrak No. 1443/J18.H8/PL01.01/97 Tanggal 20 Oktober 1997. Mataram: Universitas Mataram Press.

Stringer, Janet L. 2009. Konsep Dasar Farmakologi. Jakarta: EGC

Sudarmadji, Slamet. 1996. Teknik Analisis Biokimiawi. Yogyakarta: Liberty

Sudjadi dkk. 2007. Analisis Kuantitatif Obat. Yogyakarta: Gadjah Mada University Press. 
Svehla. 1985. Analisis Anorganik Kualitatif Makro dan Semimakro. Jakarta: PT Kalman Media Pusaka.

Tjahajati, Ida. 2007. Ilmu Penyakit Ternak III. Yogyakarta: Gadjah Mada University Press.
Winarno. 2004. Kimia Pangan Dan Gizi. Jakarta: PT Gramedia Pustaka Utama.

Yamin, Abdul Alim. 2008. "Penggunaan Antibiotik dalam Ransum Ayam Broiler". http:// alimyameen. blogspot. com. Diakses pada hari Kamis, 31/03/2011. 